\title{
Antimicrobial and antioxidant activities of protein hydrolysate from terrestrial snail Cryptozona bistrialis
}

\author{
Selvakumari Ulagesan ${ }^{1}$, Amutha Kuppusamy ${ }^{2}$, Hak Jun Kim* \\ ${ }^{1}$ Institute of Marine Biotechnology, Pukyong National University, Busan, Republic of Korea. \\ ${ }^{2}$ Department of Biotechnology, Vels University, Chennai, India. \\ ${ }^{3}$ Department of Chemistry, Pukyong National University, Busan, Republic of Korea.
}

\begin{tabular}{l}
\hline ARTICLE INFO \\
\hline Received on: $12 / 09 / 2018$ \\
Accepted on: $25 / 10 / 2018$ \\
Available online: $30 / 12 / 2018$ \\
\\
\hline Key words: \\
Cryptozona bistrialis, \\
antimicrobial activity, \\
antioxidant activity, enzyme \\
digestion, protein hydrolysate.
\end{tabular}

\section{INTRODUCTION}

Preparation of protein hydrolysates by using enzyme digestion is an important research area of current times. Hydrolysis of proteins leads to the cleavage of peptide bonds which makes proteins to peptides and amino acids. These mixtures of peptides and amino acids are called protein hydrolysates (Nnanna and $\mathrm{Wu}$, 2006). Many protein hydrolysates possess antioxidant activity (Chen et al., 1998). Enzymatic degradation makes the protein size decrease to peptide, which can modify functional characteristics and improve their quality (Petersen, 1981). Bioactive peptides obtained from various invertebrates by using different commercial enzymes have been reported as effective and safe (Rajapakse et al., 2005).

\section{"Corresponding Author}

Hak Jun Kim, Department of Chemistry, Pukyong National University, Busan, Republic of Korea.E-mail:kimhj@pknu.ac.kr
Number of enzymes has been used for hydrolysis of animal proteins such as papain, trypsin, pepsin, alcalase, etc. (Aspmo et al., 2005; Gildberg, 1993; Venugopal and Shahidi, 1995). Compared to the chemical hydrolysis, the enzymatic hydrolysis has more advantages, such as mild reaction conditions, low undesirable products, and high product quality and yield.

Protein hydrolysates are important ingredients for food and industrial applications because it contains more bioactive compounds (Sarmadi and Ismail 2010). Peptides are not showing any activity when its present inside the sequence of the proteins but its showing more activities when its released by enzymatic hydrolysis such as antimicrobial, antioxidant, antidiabetic, anti-inflammatory, and anti-hypertensive (Raghavan and Kristinsson 2009; del Carmen Millán-Linares et al., 2014; Sila et al., 2015, Maturana et al., 2017; Nongonierma et al., 2017).

In recent years, oxidative stress is the main reason for various degenerative processes and diseases such as acute and chronic inflammatory conditions such as wound (Petersen, 1981). 
Antioxidants can improve the healing of infected and non-infected wounds by reducing the damage caused by oxygen radicals (Venugopal and Shahidi, 1995). The wound healing process may be delayed by the presence of free radicals or microbial infection (Boman, 1995).

Reactive oxygen species and free radicals are the major cause of many diseases such as cancer, diabetes hypertension, neurodegenerative disorders, and aging problems. Based on the possibility of health problems, several commercial antioxidants use is regulated (Ktari et al., 2014, Zeng et al., 2015). In the past few years, there has been an increasing interest to identify antioxidants from different natural sources. Recently, we have shown that a protein extract from terrestrial snail Cryptozona bistrialis among seven different snails collected from India inhibited the growth of pathogenic bacteria and fungi (Ulagesan and Kim, 2018). In this current study, we further analyzed antibacterial and antioxidant activities of protein hydrolysates from the terrestrial snail, C. bistrialis prepared by enzymes.

\section{MATERIALS AND METHODS}

\section{Chemicals and snail}

Trypsin, papain, pepsin, DPPH (2, 2-diphenyl-1picrylhydrazyl), ABTS [2, 2'-azino-bis (3-ethylbenzothiazoline-6sulphonic acid], butylated hydroxytoluene, potassium ferricyanide, trichloroacetic acid, ferric chloride, and potassium persulfate were procured from Sigma-Aldrich. Analytical grade other chemicals and reagents were used in this experiment. The reagent was prepared freshly with deionized water. Land snails $C$. bistrialis of live species were collected from Thirumazhisai agricultural field, Chennai, Tamil Nadu, India and they were brought to the laboratory. The snail's shells were broken, and the soft body was stored at $-20^{\circ} \mathrm{C}$ prior to use.

\section{Protein hydrolysate preparation}

Three different enzymes were used to produce peptides from the protein of $C$. bistrialis. The enzymes were used at their optimal conditions: pepsin ( $0.1 \mathrm{M}$ Glycine-HCl buffer, $\mathrm{pH} 2.0$, $37^{\circ} \mathrm{C}$ temperature, and enzyme/substrate ratio $\left.1: 100 \mathrm{w} / \mathrm{w}\right)$, papain (0.1 $\mathrm{M} \mathrm{Na}_{2} \mathrm{HPO}_{4}-\mathrm{NaH}_{2} \mathrm{PO}_{4}$ buffer, $\mathrm{pH} 6.0,37^{\circ} \mathrm{C}$ temperature, and enzyme/substrate ratio $1: 100 \mathrm{w} / \mathrm{w})$, and trypsin $\left(0.1 \mathrm{M} \mathrm{Na}_{2} \mathrm{HPO}_{4}-\right.$ $\mathrm{NaH}_{2} \mathrm{PO}_{4}$ buffer, $\mathrm{pH} 8.0,37^{\circ} \mathrm{C}$ temperature, and enzyme/substrate ratio $1: 250 \mathrm{w} / \mathrm{w})$. The enzymatic digestion was carried out based on the method described elsewhere (Je et al., 2007). Enzymatic degradation was performed with three different enzymes such as pepsin, papain, and trypsin separately. The $C$. bistrialis protein was mixed with different enzymes and incubated for 6 hours in constant stirring, after incubation the mixture was heated in water bath at $100^{\circ} \mathrm{C}$ for 10 minutes, this inactivates the enzyme activity. Then, the mixture was centrifuged at $10,000 \mathrm{rpm}$ in $4^{\circ} \mathrm{C}$ for 15 minutes, the collected supernatant was the protein hydrolysate.

\section{Degree of hydrolysis}

Degree of hydrolysis (DH) was determined based on the procedure described elsewhere (Tang et al., 2009). The C. bistrialis protein was mixed with trypsin, pepsin, and papain enzymes with different enzyme/substrate ratios separately 1:100, 2:100, 4:200 $\mathrm{w} / \mathrm{w}$ and the reaction was conducted at optimal conditions of the respective enzymes, from the first to sixth hour the hydrolytic yield was measured continuously. The reaction mixture $\mathrm{pH}$ was maintained stable during the hydrolysis by using $2 \mathrm{M} \mathrm{NaOH}$, after hydrolysis, the $\mathrm{pH}$ was neutralized and the enzymes were inactivated by heating the reaction mixture at $100^{\circ} \mathrm{C}$ for 10 minutes. The protein hydrolysate was centrifuged for 15 minutes at $10,000 \mathrm{~g}$, after centrifugation the supernatant was collected and used in this study. Percentage of the DH was calculated by using the $\mathrm{pH}$-stat method by Adler-Nissen (1986). DH is described as the ratio between the number of broken peptide bonds $(h)$ and the total number of peptide bonds per mass unit $\left(h_{\text {tot }}\right)$ as shown below:

$$
\text { Percentage of } \mathrm{DH}=\frac{h}{h_{\text {tot }}} \times 100
$$

The DH of hydrolyzed protein was determined by measuring the amount of free $\alpha$-amino groups based on the reaction between Sanger's reagent of 1-fluoro-2,4-dinitrobenzene and the amino groups in the amino acids which resulted in a yellow complex of amino acids (Goodwin, 1968). The absorbance was measured at $410 \mathrm{~nm}$.

\section{Estimation of protein hydrolysate concentration}

The protein hydrolysate concentration of $C$. bistrialis by papain digestion was determined by Bradford's method and bovine serum albumin used as a standard (Bradford, 1976).

\section{Antibacterial activity}

Antibacterial assay was performed for three different enzyme digested protein hydrolysates by Agar well diffusion method against Staphylococcus aureus (MTCC 3160) and Pseudomonas aeruginosa (MTCC 424) (Bauer et al., 1966). The bacterial cultures were regularly subcultured and maintained in respective medium at $4^{\circ} \mathrm{C}$ as stock cultures, and for antibacterial assay, a loop full of culture from the stock cultures were transferred to Luria Bertani broth and were incubated for 24 hours at $37^{\circ} \mathrm{C}$, after incubation 24 hours broth bacterial cultures were swabbed in nutrient agar plates and kept for 15 minutes in a laminar chamber for absorption of cultures and $5 \mathrm{~mm}$ wells were made by using a sterile cork borer, $20 \mu \mathrm{l}$ of the three different enzyme digested protein hydrolysates at different concentrations, such as 12.5, 25, and $50 \mu \mathrm{g} / \mathrm{ml}$, were prepared and added to each well. Antibiotic chloramphenicol $(100 \mu \mathrm{g} / \mathrm{ml})$ used as positive control and distilled water was used as the negative control. The plates were incubated for 24 hours in $37^{\circ} \mathrm{C}$. The zone of inhibition was measured in millimeters by using the antibiotic zone measuring scale.

Only the papain-digested protein hydrolysate of $C$. bistrialis has activity against $S$. aureus and $P$. aeruginosa. Based on these results, papain-digested protein hydrolysate of $C$. bistrialis was selected for further studies.

\section{DPPH radical scavenging assay}

Papain enzyme digested protein hydrolysate of $C$. bistrialis was analyzed for its DPPH radical scavenging activity by using the method by Burits and Bucar (2000) with slight modification. Aliquots of the sample at different concentrations such as $0.5 \mathrm{mg} / \mathrm{ml}$ to $3.0 \mathrm{mg} / \mathrm{ml}$ were dissolved in $1 \mathrm{ml}$ distilled water separately and $4 \mathrm{ml} \mathrm{DPPH}(0.004 \%)$ in methanol added to 
the sample, the reaction mixture was incubated in dark at room temperature for 30 minutes. The optical density of the reaction mixture was read at $517 \mathrm{~nm}$. Control was prepared by using the same protocol but methanol was used to replace the sample. Percentage of DPPH radical scavenging activity was measured by using the formula,

$$
\text { Percentage of radical scavenging activity }=\frac{(B-A)}{B} \times 100
$$
the blank.

where $A$-absorbance of sample and $B$-absorbance of

\section{ABTS radical scavenging assay}

ABTS radical cation decolorization assay was performed to determine the free radical scavenging activity of the papain enzyme digested protein hydrolysate of $C$. bistrialis (Re et al., 1999). ABTS assay was performed by using the reaction mixture of (1:1) $7 \mathrm{mM}$ ABTS in water and $2.45 \mathrm{mM}$ potassium persulfate and incubated for 12-16 hours in room temperature at dark. After incubation, the ABTS reaction mixture was diluted by using methanol to get an absorbance about $0.700 \pm 0.02$ at $734 \mathrm{~nm}$. Samples were prepared in various concentrations such as $0.5-3.0$ $\mathrm{mg} / \mathrm{ml}$, they were dissolved in $1 \mathrm{ml}$ distilled water separately. After the addition of $20 \mu \mathrm{l}$ of protein hydrolysate to $980 \mu \mathrm{l}$ of diluted ABTS solution, the mixture was incubated at dark in $30^{\circ} \mathrm{C}$ for 10 minutes, the absorbance measured at $734 \mathrm{~nm}$. An appropriate solvent used as a blank. All measurements were performed in triplicates, absorbance read at $734 \mathrm{~nm}$, and the percentage of inhibition was calculated by using the formula,

$$
\text { ABTS scavenging effect }(\%)=\frac{(\mathrm{AB}-\mathrm{AA})}{(\mathrm{AB})} \times 100
$$

where $\mathrm{AB}$ is absorbance of ABTS radical with methanol and AA is absorbance of ABTS radical with sample extract/standard.

\section{Ferric reducing antioxidant power (FRAP) assay}

The ferric ion $\left(\mathrm{Fe}^{3+}\right)$ reduce the ability of the protein hydrolysate was analyzed by the protocol previously described by Pulido et al. (2000) with modifications. The ferric reducing antioxidant power (FRAP) reagent consists of acetate buffer $25 \mathrm{ml}$ (pH 3.6), $10 \mathrm{mM}$ 2,4,6-tripyridyl-s-triazine (TPTZ) $2.5 \mathrm{ml}$ in $40 \mathrm{Mm}$ $\mathrm{HCl}$, and $20 \mathrm{mM} \mathrm{FeCl}_{3} \cdot 6 \mathrm{H}_{2} \mathrm{O} 2.5 \mathrm{ml}$. Protein hydrolysate dissolved in distilled water as an aliquot of $30 \mu \mathrm{l}$ and FRAP reagent of $900 \mu \mathrm{l}$, incubated for 30 minutes at $37^{\circ} \mathrm{C}$, after incubation the absorbance of the mixture read at $595 \mathrm{~nm}$. Ferric reducing antioxidant power indicates the increased absorbance of the reaction mixture.

\section{Statistical analysis}

All experiments were performed in triplicate, and results are presented as the mean \pm standard deviation (SD). Analysis of significant differences done by one-way analysis of variance. Differences at $p<0.05$ were considered as significant.

\section{RESULTS AND DISCUSSION}

\section{Degree of hydrolysis}

Terrestrial snail C. bistrialis (Beck, 1837) was collected and identified with registration number, LM-551. Peptides will be released by enzymatic digestion of proteins. Nnanna and $\mathrm{Wu}$ (2006) stated that the enzyme-digested protein leads to the release of peptides and amino acids, they were called as protein hydrolysate. In our present work, the snail $C$. bistrialis protein was digested with three different enzymes such as papain, pepsin, and trypsin to obtain protein hydrolysates. According to Nasri et al. (2013), based on factors such as enzyme and hydrolysis time, the protein hydrolysates have variation in their amino acids composition. The percentage of peptide bond breakage was calculated by using the $\mathrm{DH}$, during hydrolysis, the proteolysis monitoring parameter was determined at various time intervals (Adler-Nissen, 1986). Higher percentage of $\mathrm{DH}$ indicates that more number of peptide was present in the solution. Sampath Kumar et al. (2011) reported that the peptides recovered after cleavage are more bioactive and antioxidant in nature. In our study, the DH of $C$. bistrialis protein was calculated with different enzyme/substrate ratio for three different enzymes and the DH were monitored at various time intervals $1-6$ hours presented in Table 1, the percentage of DH was calculated and presented in Figures $1 \mathrm{~A}-\mathrm{C}$ and 2, at the end of 6 hours was,

Table 1. Effect of different enzyme/substrate ratios in the DH of protein hydrolysate derived by papain, pepsin, and trypsin

\begin{tabular}{|c|c|c|c|c|c|c|}
\hline Enzyme & 60 minutes & 120 minutes & 180 minutes & 240 minutes & 300 minutes & 360 minutes \\
\hline \multicolumn{7}{|l|}{ Papain } \\
\hline $\mathrm{E} / \mathrm{S}=1: 100 \mathrm{w} / \mathrm{w}$ & $14.5 \pm 0.5$ & $16.3 \pm 0.57$ & $19.16 \pm 0.76$ & $22 \pm 1$ & $24 \pm 1$ & $27 \pm 0.5$ \\
\hline $\mathrm{E} / \mathrm{S}=2: 100 \mathrm{w} / \mathrm{w}$ & $15.3 \pm 0.57$ & $17 \pm 0.86$ & $20.5 \pm 0.5$ & $22.6 \pm 0.76$ & $25 \pm 0.5$ & $28.8 \pm 0.57$ \\
\hline $\mathrm{E} / \mathrm{S}=4: 100 \mathrm{w} / \mathrm{w}$ & $17.16 \pm 0.28$ & $22 \pm 1$ & $23.3 \pm 0.57$ & $24.83 \pm 0.76$ & $26.01 \pm 0.76$ & $29.5 \pm 0.5$ \\
\hline \multicolumn{7}{|l|}{ Trypsin } \\
\hline $\mathrm{E} / \mathrm{S}=1: 100 \mathrm{w} / \mathrm{w}$ & $12.6 \pm 0.14$ & $14.23 \pm 0.4$ & $15.13 \pm 0.70$ & $16.3 \pm 0.30$ & $19.16 \pm 0.40$ & $20.2 \pm 0.5$ \\
\hline $\mathrm{E} / \mathrm{S}=2: 100 \mathrm{w} / \mathrm{w}$ & $13.03 \pm 0.15$ & $13.5 \pm 0.5$ & $15.83 \pm 0.28$ & $16.46 \pm 0.25$ & $17.83 \pm 0.28$ & $21.16 \pm 0.76$ \\
\hline $\mathrm{E} / \mathrm{S}=4: 100 \mathrm{w} / \mathrm{w}$ & $14 \pm 0.5$ & $14.5 \pm 0.5$ & $16.23 \pm 0.25$ & $17 \pm 0.2$ & $17.9 \pm 0.79$ & $21.83 \pm 0.28$ \\
\hline \multicolumn{7}{|l|}{ Pepsin } \\
\hline $\mathrm{E} / \mathrm{S}=1: 100 \mathrm{w} / \mathrm{w}$ & $9.1 \pm 0.36$ & $10.23 \pm 0.25$ & $10.4 \pm 0.52$ & $11 \pm 0.2$ & $11.43 \pm 0.40$ & $12.26 \pm 0.25$ \\
\hline $\mathrm{E} / \mathrm{S}=2: 100 \mathrm{w} / \mathrm{w}$ & $9.5 \pm 0.26$ & $10.3 \pm 0.1$ & $10.6 \pm 0.30$ & $11.56 \pm 0.11$ & $11.6 \pm 0.52$ & $12.4 \pm 0.17$ \\
\hline $\mathrm{E} / \mathrm{S}=4: 100 \mathrm{w} / \mathrm{w}$ & $10.6 \pm 0.52$ & $11.43 \pm 0.40$ & $11.86 \pm 0.11$ & $12.23 \pm 0.25$ & $12.5 \pm 0.3$ & $12.66 \pm 0.28$ \\
\hline
\end{tabular}
from C. bistrialis.

The values of the $\mathrm{DH} \%$ are reported as mean of triplicates and $\pm \mathrm{SD}$ 
(A)

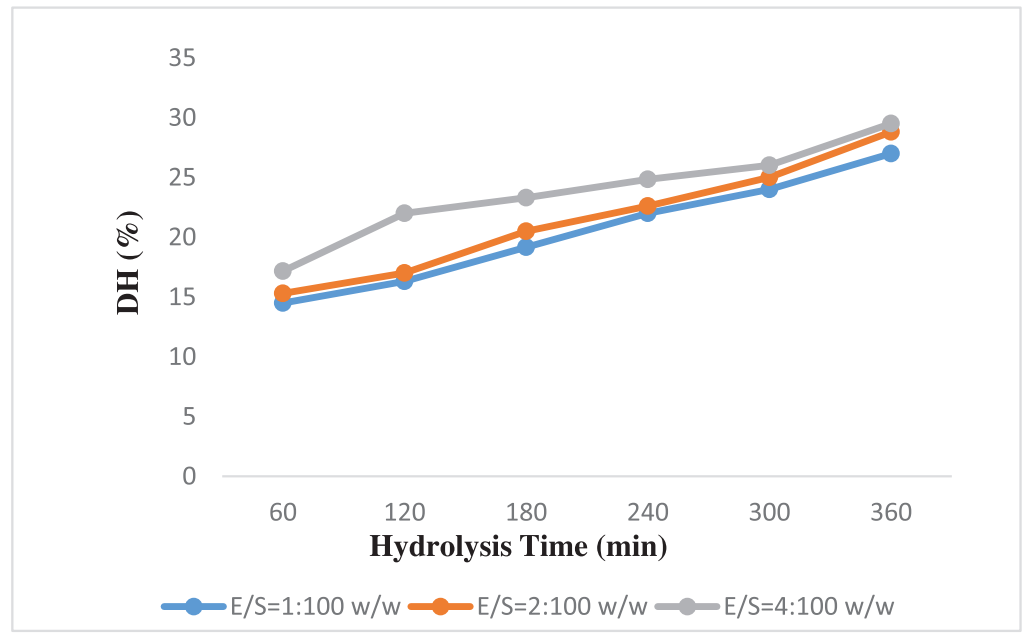

(B)

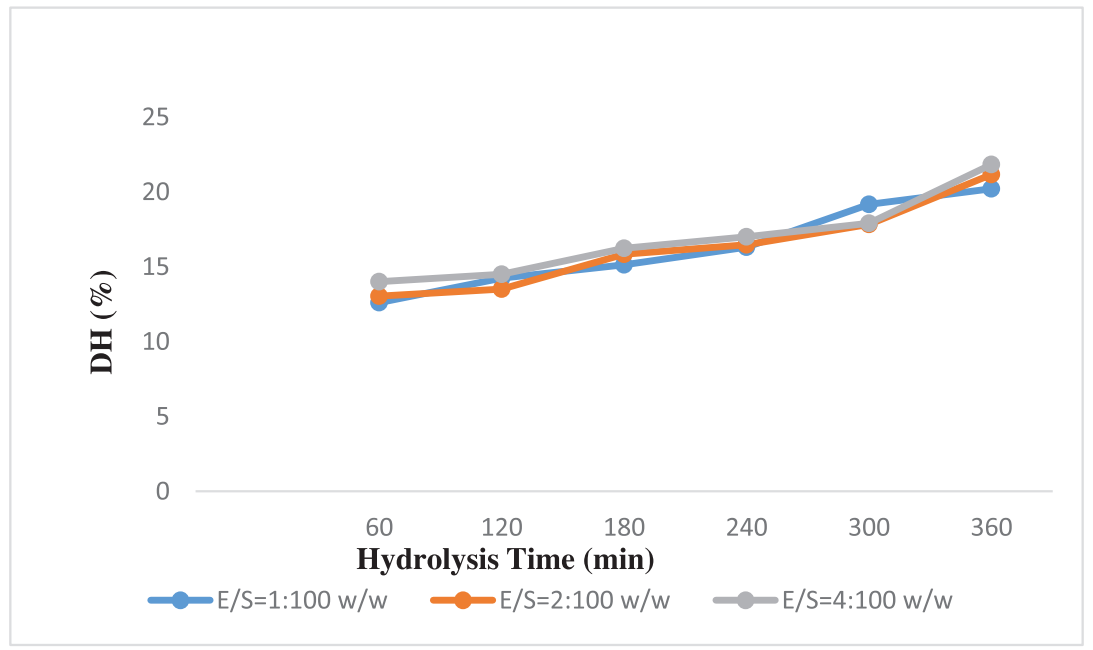

(C)

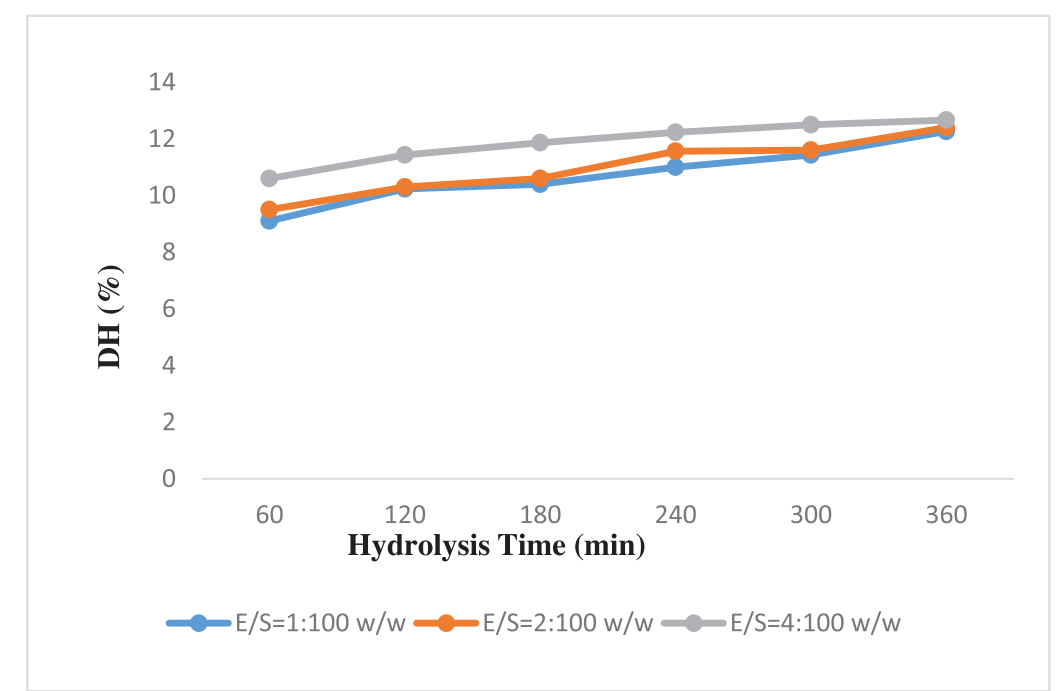

Figure 1. DH of C. bistrialis protein by various E/S ratios (A) papain, (B) trypsin, and (C) pepsin. Changes in DH of protein from C. bistrialis, hydrolysis by papain at various $\mathrm{E} / \mathrm{S}$ ratios $\mathrm{w} / \mathrm{w}(1: 100,2: 100$, and 4:100). The data were expressed as the mean of triplicates $\pm \mathrm{SD}$ measurements. 


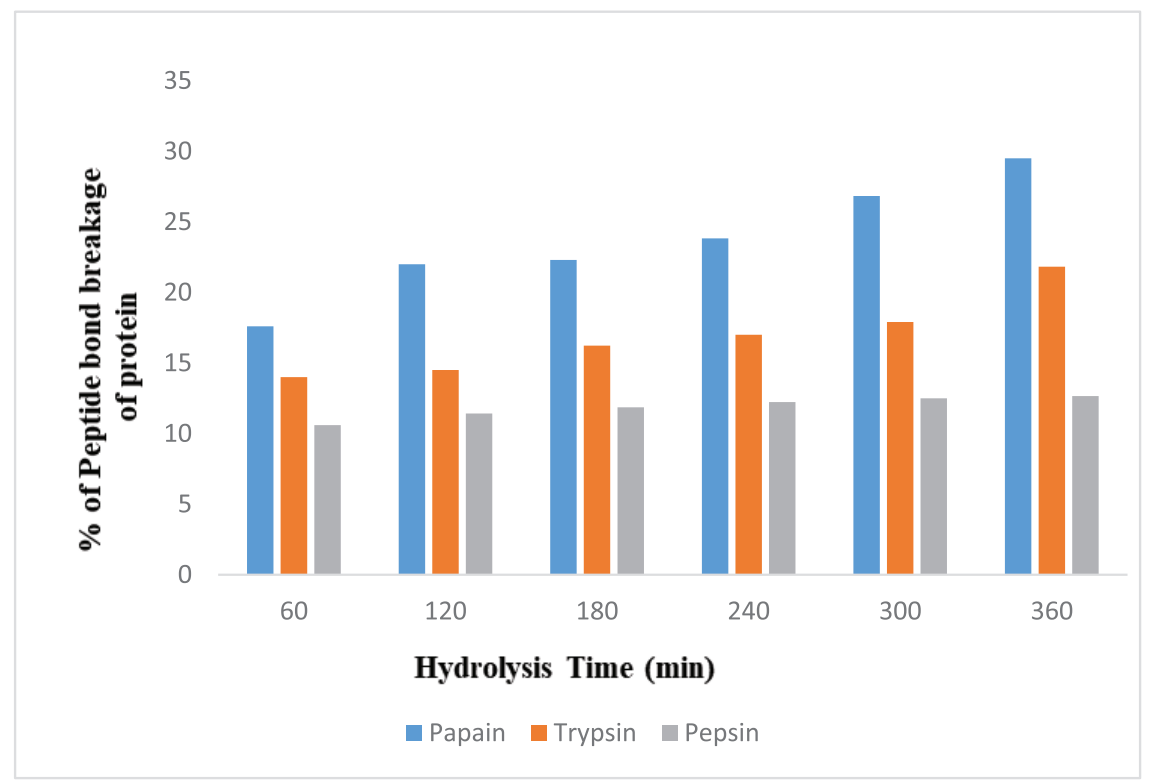

Figure 2. Percentage of peptide bond breakage of protein from C. bistrialis by three different enzymes at various time intervals. Percentage of peptide bond breakage of protein from C. bistrialis digested by papain, trypsin, and pepsin at various time intervals. The data were expressed as the mean of triplicates $\pm \mathrm{SD}$ measurements.

papain $27 \%$, trypsin $20 \%$, and pepsin $12 \%$, respectively. The higher level of breakdown $14.5 \%$ for papain, $12.6 \%$ for trypsin, and $9 \%$ for pepsin were obtained in the first hour of digestion and the percentage of peptide bond breakage increased gradually up to the 6 hours. Among the three enzymes used in our work, papain showed a higher DH than trypsin and pepsin. The present work result showed the result similar to the report of papain digestion of fish protein hydrolysate in which $22 \%$ of hydrolysis was obtained during the sixth hour (Abdulazeez et al., 2013). The hydrophobic amino acids are important for antioxidant and antimicrobial properties of protein hydrolysate, they can improve their interaction with lipid targets or entry into target organs through hydrophobic associations. Papain-digested C. bistrialis protein was $1.42 \mathrm{mg} / \mathrm{ml}$.

\section{Antibacterial activity of digested protein hydrolysates of $\boldsymbol{C}$. bistrialis}

Three different protein hydrolysates were analyzed for their antibacterial activity against $S$. aureus and $P$. aeruginosa. Only the papain-digested protein hydrolysate of $C$. bistrialis had activity against tested pathogens as shown in Figure $3 \mathrm{~A}-\mathrm{C}$ and Table 2. According to Najafian and Babji (2012), usually, the protein hydrolysates which contain cationic amino acids in their composition will show higher antimicrobial activity. Antimicrobial activity was analyzed for protein hydrolysates from fermented fishes such as goby (Zosterizessor ophiocephalus), zebra blenny (Salaria basilisca), ray (Dasyatis pastinaca), and sardinelle (Sardinella aurita) (Jemil et al. 2014). These hydrolysates inhibited both Gram-positive and Gram-negative microorganisms. The amino acid sequence is closely related to the antimicrobial activity of the protein hydrolysate (Memarpoor-Yazdi et al. 2012; Najafian and Babji, 2012). Based on these results, papaindigested protein hydrolysate of $C$. bistrialis was selected for further studies.

\section{Antioxidant activity digested of protein hydrolysate}

Antioxidant properties of papain-digested protein hydrolysate were presented in Figure 4A-C. Antioxidant properties were analyzed for different proteins from various natural bioresources such as bullfrog skin and porcine collagen and the protein hydrolysate of round scad (Decapterus maruadsi) analyzed for its antioxidant activity (Thiansilakul et al.2007). Peptides were purified and analyzed for its antioxidant activity from giant squid muscle (Rajapakse et al.2005). In our study, effective results of antioxidant potential protein hydrolysate from $C$. bistrialis were obtained. Two different radicals such as DPPH and ABTS scavenged by protein hydrolysate, it might be governed by a difference in chain length, amino acid side chain, and hydrophobicity. In a protein hydrolysate, the amino acid composition is an important factor for antioxidant activities. Chi et al. (2015) stated that the protein hydrolysate of Skipjack tuna showed higher radical scavenging activity because of the presence of hydrophobic and aromatic amino acids.

Normally, the hydrogen-donating potential of protein hydrolysate is determined by DPPH radical scavenging activity (Thiansilakul et al., 2007). DPPH is a free radical, it gave a maximum absorbance at $517 \mathrm{~nm}$ at an appropriate environment, the absorbance will be reduced and the color will be changed from purple to yellow, when the DPPH facing a hydrogendonating substance, such as an antioxidant (Nalinanon et al., 2011; Shimada et al., 1992). This proves the peptide has maximally $73 \%$ radical scavenging activity. In this study, when we increased the concentration of protein hydrolysate, the radical scavenging activity also increased. Similar results were reported on Nemipterus japonicas and Exocoetus volitans (Yousuf Naqash and Nazeer, 2010) in which radical scavenging activity was proportional to peptide concentration. Papain-digested hydrolysate used in the present study reached scavenging activity equal to that of butylated hydroxytoluene, a synthetic antioxidant. Bougatef et al. (2009) reported protein hydrolysate from Mustelus mustelus contained 
(A)

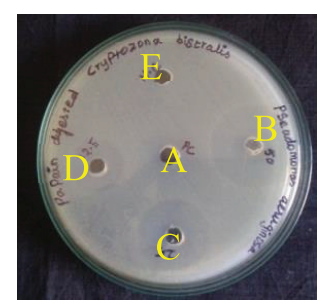

Pseudomonas aeruginosa

(B)

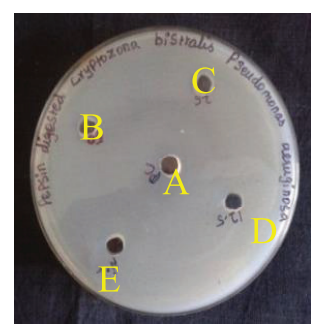

Pseudomonas aeruginosa

(C)

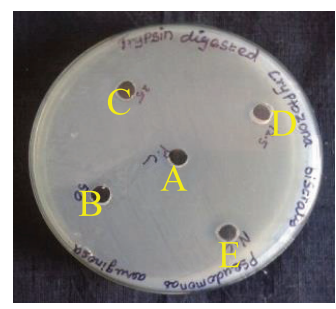

Pseudomonas aeruginosa

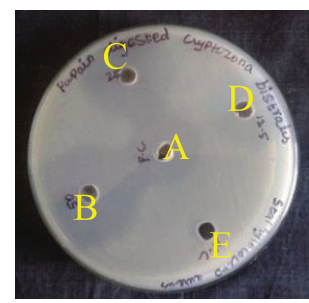

Staphylococcus aureus

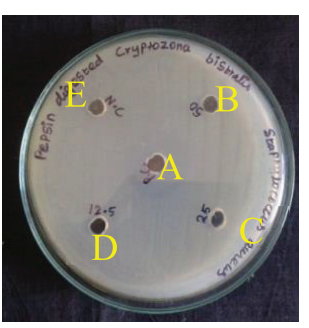

Staphylococcus aureus

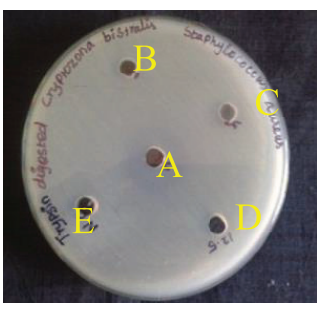

Staphylococcus aureus

Figure 3. Antibacterial activity of protein hydrolysate of C. bistrialis prepared by (A) papain, (B) pepsin, and (C) trypsin. In each plate, positive control (chloramphenicol, $100 \mu \mathrm{g} / \mathrm{ml}$ ) and negative control were labeled as A and E, respectively, $50 \mu \mathrm{g} / \mathrm{ml}$ was B, $25 \mu \mathrm{g} / \mathrm{ml}$ was C, and $12.5 \mu \mathrm{g} / \mathrm{ml}$ of protein hydrolysate was D.

Table 2. Antibacterial Activity of three different enzyme digested protein hydrolysates of $C$. bistrialis.

\begin{tabular}{|c|c|c|c|c|c|c|}
\hline \multirow{2}{*}{ Enzyme digest } & \multirow{2}{*}{ Microorganisms } & \multicolumn{5}{|c|}{ Zone of inhibition in $\mathrm{mm}$} \\
\hline & & $50 \mu \mathrm{g} / \mathrm{ml}$ & $25 \mu \mathrm{g} / \mathrm{ml}$ & $12.5 \mu \mathrm{g} / \mathrm{ml}$ & N.C (mm) & Chloramphenicol $(100 \mu \mathrm{g} / \mathrm{ml})$ \\
\hline \multirow[t]{2}{*}{ Papain digest } & Pseudomonas aeruginosa & $27.3 \pm 0.5$ & $24 \pm 1$ & $18.3 \pm 0.5$ & - & $28 \pm 0.5$ \\
\hline & Staphylococcus aureus & $28.3 \pm 0.5$ & $25.5 \pm 0.5$ & $22.8 \pm 1.2$ & - & $30.6 \pm 0.6$ \\
\hline \multirow[t]{2}{*}{ Pepsin digest } & Pseudomonas aeruginosa & - & - & - & - & $15.6 \pm 0.57$ \\
\hline & Staphylococcus aureus & - & - & - & - & $17.3 \pm 0.5$ \\
\hline \multirow[t]{2}{*}{ Trypsin digest } & Pseudomonas aeruginosa & - & - & - & - & $18.3 \pm 0.76$ \\
\hline & Staphylococcus aureus & - & - & - & - & $30.8 \pm 0.28$ \\
\hline
\end{tabular}

Antibacterial activity of three different enzyme digested protein hydrolysates of $C$. bistrialis. The data were expressed as the mean of triplicates \pm SD measurements.

antioxidant activity which can reduce Fe3+ / ferricyanide complex to ferrous form. Zhu et al. (2006) showed that peptide hydrolysate could decrease oxidation by binding with iron and chelating preoxidative iron. Commonly, FRAP assay is performed to analyze the ability to reducing TPTZ-Fe(III) complex to TPTZ-Fe(II) complex (Binsan et al. 2008). The significant Ferric reducing the antioxidant ability and maximum $70 \%$ of ABTS radical scavenging activity obtained in the present study and confirms the antioxidant property of $C$. bistrialis protein hydrolysate.

In summary, papain digested the $\mathrm{C}$. bistrialis protein with highest $\mathrm{DH}$. The protein hydrolysate showed antibacterial activity against pathogenic bacteria and antioxidant acitivity. From these results we concluded that the protein hydrolysate of C. bistrialis could be an efficient source for natural antibacterial and antioxidant agents. Further optimization for hydrolysis condition using response surface methodology and characterization may be needed for future biomedical applications.

\section{FUNDING}

This work is supported by Pukyong National University 
(A)

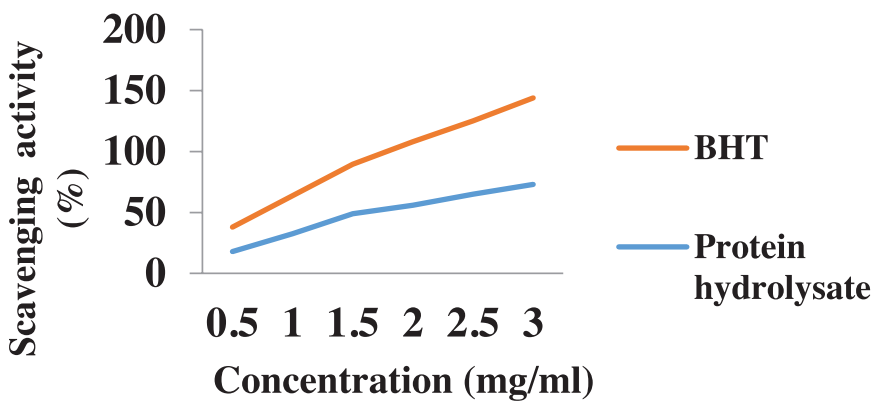

(B)

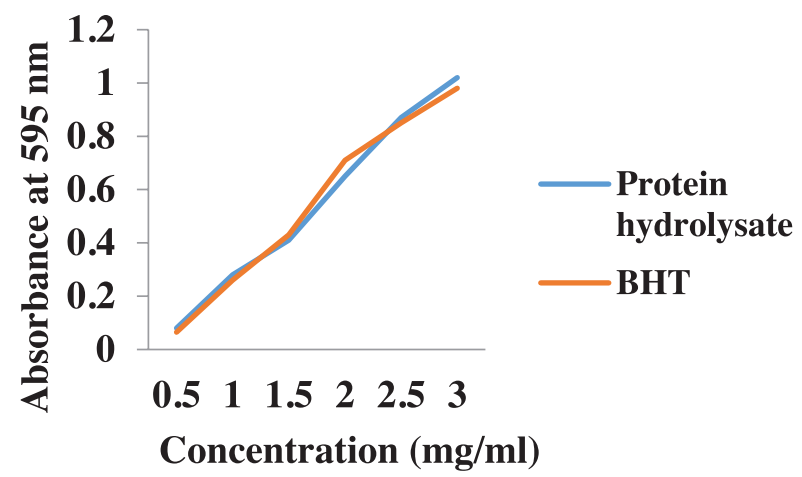

(C)

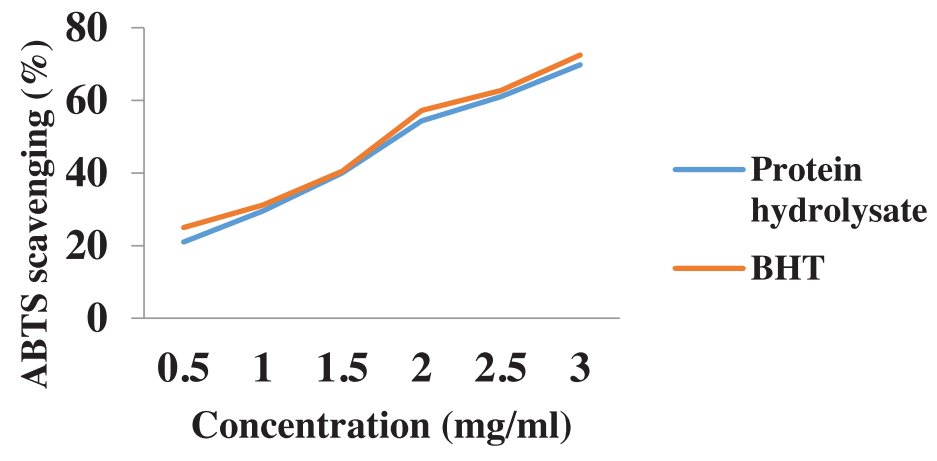

Figure 4. Antioxidant activity of protein hydrolysate from C. bistrialis. (A) DPPH radical scavenging activity, (B) FRAP assay, and (C) ABTS radical scavenging assay. The data were expressed as the mean of triplicates \pm SD measurements.

\section{REFERENCES}

Abdulazeez SS, Ramamoorthy B, Ponnusamy P. Proximate analysis and production of protein hydrolysate from King Fish of Arabian Gulf Coast-Saudi Arabia. Int J Pharmacy Biol Sci, 2013; 3(1):138-44.

Adler-Nissen J. Enzymic hydrolysis of proteins for increased solubility. J Agr Food Chem, 1976; 24(6):1090-3.

Aspmo SI, Horn SJ, Eijsink VGH. Enzymatic hydrolysis of Atlantic cod (Gadus morhua L.) viscera. Process Biochem, 2005; 40(5):1957-66.

Bauer AW, Kirby WM, Sherris JC, Turck M. Antibiotic susceptibility testing by a standardized single disk method. Am J Clin Pathol, 1966; 45(4):493-6.

Beck, Ind. Moll. Index Molluscorura Musei Prince Christiani Frederici. H. Beck. Hafnise, 1837.
Binsan W, Benjakul S, Visessanguan W, Roytrakul S, Tanaka M, Kishimura H. Antioxidative activity of Mungoong, an extract paste, from the cephalothorax of white shrimp (Litopenaeus vannamei). Food Chem, 2008; 106(1):185-93.

Boman HG. Peptide antibiotics and their role in innate immunity. Ann Rev Immunol, 1995; 13:61-92.

Bougatef A, Hajji M, Balti R, Lassoued I, Triki-Ellouz Y, Nasri M. Antioxidant and free radical-scavenging activities of smooth hound (Mustelus mustelus) muscle protein hydrolysates obtained by gastrointestinal proteases. Food Chem, 2009; 114(4):1198-205.

Bradford MM. A rapid and sensitive method for the quantitation of microgram quantities of protein utilizing the principle of protein-dye binding. Anal Biochem, 1976; 72(1-2):248-54. 
Burits M, Bucar F. Antioxidant activity of Nigella sativa essential oil. Phytother Res, 2000; 14(5):323-8.

del Carmen Millán-Linares M, Bermúdez B, Yust M, Millán F, Pedroche J. Anti-inflammatory activity of lupine (Lupinus angustifolius L.) protein hydrolysates in THP-1-derived macrophages. J Funct Foods, 2014; 8:224-33.

Chalamaiah M, Dinesh Kumar B, Hemalatha R, Jyothirmayi T. Fish protein hydrolysates: proximate composition, amino acid composition, antioxidant activities and applications: a review. Food Chem, 2012; 135(4):3020-38.

Chen HM, Muramoto K, Yamauchi F, Fujimoto K, Nokihara K. Antioxidative properties of histidine-containing peptides designed from peptide fragments found in the digests of a soybean protein. J Agric Food Chem, 1998; 46(1):49-53.

Chi C-F, Hu F-Y, Wang B, Li Z-R, Luo H-Y. Influence of amino acid compositions and peptide profiles on antioxidant capacities of two protein hydrolysates from Skipjack Tuna (Katsuwonus pelamis) dark muscle. Mar Drugs, 2015; 13(5):2580-601.

ChuanHe T, Jing P, DaWen Z, Zhong C. Physicochemical and antioxidant properties of buckwheat (Fagopyrum esculentum Moench) protein hydrolysates. Food Chemistry. Oxford: Elsevier; 2009;115(2):672-8.

Gildberg A. Enzymic processing of marine raw materials. Process Biochem, 1993; 28(1):1-15.

Goodwin JF. The colorimetric estimation of plasma amino nitrogen with DNFB. Clin Chem, 1968; 14(11):1080-90.

Intarasirisawat $\mathrm{R}$, Benjakul $\mathrm{S}$, Visessanguan $\mathrm{W}$, Wu $\mathrm{J}$. Antioxidative and functional properties of protein hydrolysate from defatted skipjack (Katsuwonous pelamis) roe. Food Chem, 2012; 135(4):3039-48.

Je J-Y, Qian Z-J, Byun H-G, Kim S-K. Purification and characterization of an antioxidant peptide obtained from tuna backbone protein by enzymatic hydrolysis. Process Biochem, 2007; 42(5):840-6.

Jemil I, Jridi M, Nasri R, Ktari N, Ben Slama-Ben Salem R, Mehiri M, Hajji M, Nasri M. Functional, antioxidant and antibacterial properties of protein hydrolysates prepared from fish meat fermented by Bacillus subtilis A26. Process Biochem, 2014; 49(6):963-72.

Ktari N, Nasri R, Mnafgui K, Hamden K, Belguith O, Boudaouara T, A EF, Nasri M. Antioxidative and ACE inhibitory activities of protein hydrolysates from zebra blenny (Salaria basilisca) in alloxaninduced diabetic rats. Process Biochem, 2014; 49(5):890-7.

Maturana P, Martinez M, Noguera ME, Santos NC, Disalvo EA, Semorile L, Maffia PC, Hollmann A. Lipid selectivity in novel antimicrobial peptides: Implication on antimicrobial and hemolytic activity. Colloids Surf B Biointerfaces, 2017; 153:152-9.

Memarpoor-Yazdi M, Asoodeh A, Chamani JK. A novel antioxidant and antimicrobial peptide from hen egg white lysozyme hydrolysates. J Funct Foods, 2012; 4(1):278-86.

Najafian L, Babji AS. A review of fish-derived antioxidant and antimicrobial peptides: their production, assessment, and applications. Peptides, 2012; 33(1):178-85.

Nalinanon S, Benjakul S, Kishimura H, Shahidi F. Functionalities and antioxidant properties of protein hydrolysates from the muscle of ornate threadfin bream treated with pepsin from skipjack tuna. Food Chem, 2011; 124(4):1354-62.

Nasri R, Younes I, Jridi M, Trigui M, Bougatef A, NedjarArroume N, Dhulster P, Nasri M, Karra-Châabouni M. ACE inhibitory and antioxidative activities of Goby (Zosterissessor ophiocephalus) fish protein hydrolysates: effect on meat lipid oxidation. Food Res Int, 2013; 54(1):552-61.

Nnanna IA, Wu C. Dairy Protein hydrolysates. Handbook of food products manufacturing. Wiley, USA, pp 537-56, 2006.
Nongonierma A, Paolella S, Mudgil P, Maqsood S, FitzGerald R. Dipeptidyl peptidase IV (DPP-IV) inhibitory properties of camel milk protein hydrolysates generated with trypsin. J Funct Foods, 2017; 34:49-58.

Petersen BR (ed.). The impact of the enzymic hydrolysis process on recovery and use of proteins. In: Enzymes and food processing. Springer; 1981. p. 149-75.

Pulido R, Bravo L, Saura-Calixto F. Antioxidant activity of dietary polyphenols as determined by a modified ferric reducing/antioxidant power assay. J Agric Food Chem, 2000; 48(8):3396-402.

Raghavan S, Kristinsson HG. ACE-inhibitory activity of tilapia protein hydrolysates. Food Chem, 2009; 117(4):582-8.

Rajapakse N, Mendis E, Byun H-G, Kim S-K. Purification and in vitro antioxidative effects of giant squid muscle peptides on free radicalmediated oxidative systems. J Nutr Biochem, 2005; 16(9):562-9.

Re R, Pellegrini N, Proteggente A, Pannala A, Yang M, RiceEvans C. Antioxidant activity applying an improved ABTS radical cation decolorization assay. Free Radic Biol Med, 1999; 26(9-10):1231-7.

Sampath Kumar NS, Nazeer RA, Jaiganesh R. Purification and biochemical characterization of antioxidant peptide from horse mackerel (Magalaspis cordyla) viscera protein. Peptides, 2011; 32(7):1496-501.

Sarmadi BH, Ismail A. Antioxidative peptides from food proteins: a review. Peptides, 2010; 31(10):1949-56.

Shimada K, Fujikawa K, Yahara K, Nakamura T. Antioxidative properties of xanthan on the autoxidation of soybean oil in cyclodextrin emulsion. J Agric Food Chem, 1992; 40(6):945-8.

Sila A, Martinez-Alvarez O, Haddar A, Gomez-Guillen MC, Nasri M, Montero MP, Bougatef A. Recovery, viscoelastic and functional properties of Barbel skin gelatine: investigation of anti-DPP-IV and antiprolyl endopeptidase activities of generated gelatine polypeptides. Food Chem, 2015; 168:478-86.

Tang CH, Jing P, DaWen Z, Zhong C. Physicochemical and antioxidant properties of buckwheat (Fagopyrum esculentum Moench) protein hydrolysates. Food Chem, 2009; 115(2):672-8.

Thiansilakul Y, Benjakul S, Shahidi F. Compositions, functional properties and antioxidative activity of protein hydrolysates prepared from round scad (Decapterus maruadsi). Food Chem, 2007; 103(4):1385-94.

Ulagesan S, Kim JH. Antibacterial and antifungal activities of proteins extracted from seven different snails. Appl Sci, 2018; 8(8), 1362

Venugopal V, Shahidi F. Value-added products from underutilized fish species. Crit Rev Food Sci Nutr, 1995; 35(5):431-53.

Yousuf Naqash S, Nazeer RA. Antioxidant activity of hydrolysates and peptide fractions of Nemipterus japonicus and Exocoetus volitans Muscle. J Aquat Food Product Technol, 2010; 19(3):180-92.

Zeng W-C, Zhang W-H, He Q, Shi B. Purification and characterization of a novel antioxidant peptide from bovine hair hydrolysates. Process Biochem, 2015; 50(6):948-54.

Zhu K, Zhou H, Qian H. Antioxidant and free radical-scavenging activities of wheat germ protein hydrolysates (WGPH) prepared with alcalase. Process Biochem, 2006; 41(6):1296-302.

How to cite this article:

Ulagesan S, Kuppusamy A, Kim HJ. Antimicrobial and antioxidant activities of protein hydrolysate from terrestrial snail Cryptozona bistrialis. J App Pharm Sci, 2018; 8(12): 012-019. 